\title{
INTERVENSI GIZI DAN RAMUAN JAMU UNTUK DIABETES TERHADAP KADAR GULA DARAH DI RRJ HORTUS MEDICUS
}

\author{
Enggar Wijayanti, Ulfa Fitriani, Ulfatun Nisa \\ Balai Besar Penelitian dan Pengembangan \\ Tanaman Obat dan Obat Tradisional Tawangmangu \\ Badan Litbangkes Kementrian Kesehatan RI \\ Jl. Raya Lawu No. 11 Tawangmangu Karanganyar Jawa Tengah \\ e-mail : enggarwj.189@gmail.com
}

\begin{abstract}
ABSTRAK
Diabetes Mellitus (DM) adalah penyakit metabolik yang berlangsung kronik progresif, dengan gejala hiperglikemi, yang disebabkan oleh gangguan sekresi insulin, gangguan kerja insulin, atau keduanya. Prevalensi penderita DM di dunia maupun di Indonesia meningkat dari tahun ke tahun. Penatalaksanaan diabetes mellitus meliputi edukasi, terapi gizi medis, latihan jasmani/aktivitas fisik serta intervensi farmakologi. Ramuan jamu yang terdiri atas Sambiloto (Andrographis paniculata), Brotowali (Tinospora crispa), Temulawak (Curcuma xanthorrhiza), kunyit (Curcuma domestica) dan Meniran (Phyllanthus niruri) melalui uji praklinik dan klinik telah terbukti dapat menurunkan kadar gula darah. Di Rumah Riset Jamu (RRJ) "Hortus Medicus" selama ini belum dilakukan intervensi gizi terhadap penderita DM tipe 2. Penelitian ini bertujuan untuk melihat pengaruh intervensi gizi dan ramuan jamu anti diabetes terhadap kadar gula darah pasien di RRJ "Hortus Medicus". Penelitian ini menggunakan desain penelitian the one group pre and post test. Intervensi gizi berupa edukasi gizi dan diet dilakukan selama kurang lebih 30 menit dilakukan pada saat pasien datang pertama kali serta dilakukan pengukuran kadar dula darah sewaktu. Selama 28 hari pasien juga diberikan ramuan jamu untuk diabetes. Setelah 28 hari kemudian dilakukan pemeriksaan kadar gula darah sewaktu dan evaluasi terhadap program diet. Penelitian yang telah dilakukan pada 35 orang subjek, terdapat penurunan kadar gula darah, hasil uji tberpasangan menunjukkan perbedaan kadar gula darah sebelum dan sesudah intervensi ( $p$ value $<0,05$ ). Intervensi gizi dan ramuan jamu untuk diabetes pada penderita DM tipe 2 di RRJ Hortus Medicus Tawangmangu mampu menurunkan kadar gula darah sewaktu.
\end{abstract}

Kata kunci: Diabetes mellitus, intervensi gizi, ramuan jamu, kadar gula darah

\begin{abstract}
Diabetes mellitus (DM) is a metabolic disease that lasts a chronic progressive, with symptoms of hyperglycemia, which is caused by impaired insulin secretion, impaired insulin action, or both. The prevalence of diabetic patients in the world and in Indonesia increased from year to year. Management of diabetes mellitus are education, nutritional counseling, exercise and farmacology intervention. Herbs which consist of Sambiloto (Andrographis paniculata), Brotowali (Tinospora crispa), Temulawak (Curcuma xanthorrhiza), kunyit (Curcuma domestica) dan Meniran (Phyllanthus niruri) can decreases blood glucosa level based on pre-clinical and clinical study. Rumah Riset Jamu (RRJ) "Hortus Medicus" has
\end{abstract}


not done nutritional counseling to patients with diabetes mellitus type 2 . This study aims to look at the effect of nutritional counseling and herbs for diabetes to blood glucose levels of diabetic patients in RRJ "Hortus Medicus". This study is preexperimental with the one group pretest and posttest design. Nutritional intervention which consist of nutritional and dietary counseling carried out for approximately 30 minutes when the patient comes first and the blood glucosa levels of patient was examined in the laboratory RRJ. For 28 days, patient must drinking herbs for diabetes. After 28 days later, blood glucose levels and dietary of patient was evaluated. The study was conducted on 35 subjects shown that the nutrition intervention and herbs for diabetes were decreases blood glucosa levels, paired t-test results showed a significant difference blood glucose levels before and after ( $p$ value $<0.05$ ). Nutritional intervention and herbs for diabetes in patients with type 2 diabetes mellitus in RRJ Hortus Medicus Tawangmangu able to decrease in blood glucose levels.

Keywords: Diabetes mellitus, nutritional intervention, herbs, blood glucose levels

\section{PENDAHULUAN}

Diabetes mellitus (DM) adalah penyakit metabolik yang berlangsung kronik progresif, dengan gejala hiperglikemi yakni ditandai dengan kenaikan kadar gula darah puasa $>126$ $\mathrm{mg} / \mathrm{dL}$ atau gula darah sewaktu $\geq 200$ $\mathrm{mg} / \mathrm{dL}$, yang disebabkan oleh gangguan sekresi insulin, gangguan kerja insulin, atau keduanya. ${ }^{1,2,3}$ WHO pada September 2012 menjelaskan bahwa jumlah penderita DM di dunia mencapai 347 juta orang dan lebih dari $80 \%$ kematian akibat DM terjadi pada negara miskin dan berkembang. $^{2}$ Penelitian Askandar Tjokroprawiro menunjukkan jumlah penderita DM di dunia dari 110,4 juta pada tahun 1994 melonjak 1,5 kali lipat (175,4 juta) pada tahun 2000 dan melonjak dua kali lipat (239,3 juta) pada tahun 2010. ${ }^{4}$ Berdasarkan hasil Riskesdas yang dilakukan oleh Badan Litbang Kementerian Kesehatan RI terdapat kenaikan prevalensi nasional DM dari tahun 2007 sebesar 1,1\% menjadi 2,1\% pada tahun 2013. ${ }^{5}$

$$
\text { Meningkatnya prevalensi }
$$

komplikasi DM di Indonesia, diduga ada hubungannya dengan cara hidup (pola makan) seiring dengan kemakmuran yang meningkat. Pola makan bergeser dari pola makan tradisional yang banyak mengandung karbohidrat, serat dan sayuran ke pola makan kebarat-baratan dengan komposisi yang terlalu banyak mengandung protein, lemak, gula, garam, dan sedikit serat. ${ }^{5}$

DM tipe 2 sering terjadi pada middle aged dan orang yang lebih tua, dengan puncak onset pada usia 60 tahun. DM tipe 2 lebih sering terjadi dari DM tipe 1 yakni $90-95 \%$ dari kasus DM merupakan DM tipe 2. ${ }^{6}$ Diabetes Mellitus merupakan penyakit kronik yang sulit disembuhkan, tetapi sangat potensial untuk dikendalikan. Menurut Perkumpulan Endokrinologi Indonesia (PERKENI) tahun 2011 terdapat empat pilar penatalaksanaan diabetes melitus yaitu; edukasi, terapi gizi medis, latihan jasmani/aktivitas fisik serta intervensi farmakologi. ${ }^{7}$ Berdasarkan studi yang dilakukan Miller, bahwa pengetahuan responden tentang pengelolaan DM sangat penting untuk mengontrol kadar glukosa darah. ${ }^{8}$ Penderita DM yang mempunyai pengetahuan rendah tentang pengelolaan DM memiliki risiko kadar glukosa darahnya tidak terkendali 2-3 kali lebih besar dibanding dengan responden yang memiliki pengetahuan yang cukup. Pengetahuan dapat diberikan melalui edukasi. Pemberian edukasi dapat diberikan secara personal atau kelompok. ${ }^{9}$ Berdasarkan teknik komunikasi, salah satu metode edukasi adalah melalui penyuluhan langsung yakni dengan cara konseling gizi. ${ }^{10}$ 
Istilah jamu sudah tidak asing bagi masyarakat Indonesia. Jamu merupakan obat asli Indonesia yang telah digunakan secara turun temurun oleh masyarakat luas untuk menjaga kesehatan dan pengobatan. Meskipun saat ini sudah banyak terdapat obat-obatan modern yang beredar, kepercayaan masyarakat terhadap jamu masih cukup besar. Hal ini ditunjukkan dengan masih maraknya pengobatan alternatif yang menggunakan jamu sebagai salah satu cara pengobatan. Menurut data Riskesdas tahun 2010, persentase masyarakat Indonesia yang pernah mengkonsumsi jamu sebanyak $59,12 \% .{ }^{11}$ Selain itu, dengan adanya program Saintifikasi Jamu dari Kementerian Kesehatan, membuat kepercayaan masyarakat terhadap khasiat dan keamanan jamu semakin meningkat, karena akan didukung oleh data-data ilmiah. $^{12}$

Sambiloto

(Andrographis paniculata) dan Brotowali (Tinospora crispa) adalah tanaman obat yang secara tunggal (sendiri-sendiri) mempunyai aktifitas tinggi dalam menurunkan kadar gula darah. ${ }^{13,14}$ Temulawak (Curcuma xanthorrhiza) digunakan untuk menyegarkan tubuh, melancarkan metabolisme serta menyehatkan fungsi hati, kunyit (Curcuma domestica) digunakan untuk melancarkan pencernaan dan meniran (Phyllanthus niruri) untuk meningkatkan daya tahan tubuh. ${ }^{14}$ Ramuan yang terdiri atas 5 tanaman obat tersebut telah digunakan dalam klinik Saintifikasi Jamu Hortus Medicus sebagai penurun kadar gula darah.

Data rekam medis di Rumah Riset Jamu "Hortus Medicus" tercatat pasien dengan diagnosa Diabetes Mellitus tipe 2 merupakan jumlah pasien terbanyak ke-2 pada tahun 2013. Di Rumah Riset Jamu (RRJ) "Hortus Medicus" selama ini belum pernah dilakukan konseling gizi oleh ahli gizi terhadap penderita DM tipe 2.

\section{TUJUAN PENELITIAN}

Penelitian ini bertujuan untuk melihat pengaruh intervensi gizi dan ramuan jamu anti diabetes terhadap kadar gula darah pasien di RRJ“" Hortus Medicus".

\section{METODE PENELITIAN}

\section{$\begin{array}{lll}\text { TEMPAT } & \text { DAN WAKTU }\end{array}$ PENELITIAN}

Penelitian ini dilakukan di Rumah Riset Jamu (RRJ) "Hortus Medicus" Tawangmangu, mulai dari bulan Maret sampai dengan bulan Oktober 2015.

\section{DESAIN PENELITIAN}

Penelitian ini merupakan penelitian Pre-Experimental, dengan desain The one group pretest and post test design. Dalam rancangan ini digunakan satu kelompok subjek. Intervensi gizi berupa edukasi gizi dan diet dilakukan selama kurang lebih 30 menit dilakukan pada saat pasien datang pertama kali serta dilakukan pengukuran kadar dula darah sewaktu. Selama 28 hari pasien juga diberikan ramuan jamu untuk diabetes. Setelah 28 hari kemudian dilakukan pemeriksaan kadar gula darah sewaktu dan evaluasi terhadap program diet.

\section{JUMLAH SAMPEL}

Populasi : semua pasien DM Tipe 2 yang berkunjung ke Rumah Riset Jamu (RRJ)"Hortus Medicus" Tawangmangu.

Sampel : pasien DM Tipe 2 yang melakukan pemeriksaan kadar gula darah di laboratorium kimia darah di Rumah Riset Jamu (RRJ) "Hortus Medicus" Tawangmangu dan memenuhi kriteria inklusi. 
Besar sampel dihitung

berdasarkan rumus:

$$
\mathrm{N} \mathrm{Z}^{2}{ }_{1-\alpha / 2} \mathrm{P}(1-\mathrm{P})
$$

$$
\mathrm{n}=\mathrm{-}(\mathrm{N}-1) \mathrm{d}^{2}+\mathrm{Z}_{1-\alpha / 2}^{2} \mathrm{P}(1-\mathrm{P})
$$

dimana :

$$
\begin{aligned}
& \mathrm{n} \quad=\text { besar sampel minimum } \\
& \mathrm{Z}_{1-\alpha / 2}=1,96 \text { pada } \alpha 0,05 \\
& \mathrm{P} \quad=\text { harga proporsi di populasi( yakni } 0,5) \\
& \mathrm{d} \quad=\text { presisi ditetapkan }(10 \%) \\
& \mathrm{N}=\text { jumlah pengunjung rata-rata per bulan pasien } \\
& \text { DM tipe } 2 \text { di RRJ "Hortus Medicus" (54 } \\
& \text { orang) }
\end{aligned}
$$

Dari rumus perhitungan sampel diatas, didapat sampel minimal sebanyak $34,797 \approx 35$ subjek. Pengambilan sampel dilakukan secara simple random sampling.

\section{KRITERIA INKLUSI DAN EKSKLUSI}

Kriteria Inklusi adalah pasien pengunjung RRJ yang telah terdiagnosa DM tipe 2 (kadar gula darah sewaktu $\geq 200$ $\mathrm{mg} / \mathrm{dL}$ disertai keluhan klasik DM), mendapat ramuan jamu untuk diabetes, berusia 35-65 tahun, belum pernah diberi konseling gizi dan bersedia menjadi responden. Kriteria Eksklusi antara lain pasien DM dengan komplikasi yang dapat mempengaruhi pemeriksaan kadar gula dalam darah (ketoasidosis diabetik, retinopati, nefropati, neuropatidan kelainan yang melibatkan jantung dan pembuluh darah), sudah pernah mendapat konseling gizi, serta meminum obat penurun gula darah atau mendapat terapi insulin.

\section{PROSEDUR KERJA}

a. Subjek penelitian yang telah menandatangani informed consent, pada hari sebelum intervensi (H0) dilakukan anamnesis identitas subjek, riwayat penyakit, gejala klinis, dan pemeriksaan fisik diagnostik, kemudian subjek diberi pengantar untuk melakukan pemeriksaan kadar gula darah sewaktu di laboratorium RRJ serta memenuhi kriteria inklusi selanjutnya dirujuk oleh dokter untuk konsul gizi ke bagian gizi.

b. Di bagian Gizi, pasien diberi konseling gizi dengan bantuan leaflet yang berisi informasi mengenai penyakit, anjuran diet, dan daftar penukar bahan makanan (DKBM) bagi penderita DM selama \pm 30 menit.

c. Mulai hari pertama intervensi (H1) subjek penelitian diberi ramuan jamu untuk diabetes selama 28 hari.

d. Setelah \pm 28 hari subjek minum jamu, subjek datang kembali di Rumah Riset Jamu untuk selanjutnya dilakukan pemeriksaan kadar gula darah. Pada pemeriksaan darah ini, darah yang diambil adalah darah vena sebanyak 3 cc untuk kemudian diukur kadar gula darah sewaktu dengan menggunakan alat Urit 8030 (kimia analyzer) oleh tenaga analis kesehatan di Laboratorium Kimia Darah di RRJ “ Hortus Medicus".

e. Setelah data kadar gula darah terkumpul, maka dilakukan analisis dengan uji t berpasangan.

\section{HASIL DAN PEMBAHASAN}

\section{KARAKTERISTIK DEMOGRAFI SUBJEK}

Subjek dalam penelitian ini merupakan pasien yang berobat di RRJ Hortus Medicus Tawangmangu dan terdiagnosis menderita Diabetes Mellitus tipe 2 serta bersedia berpartisipasi dalam penelitian ini. . Karakteristik responden berdasarkan jenis kelamin, umur, pekerjaan dan tingkat pendidikan disajikan pada tabel 1 . 
Tabel 1. Gambaran umum subjek menurut umur, jenis kelamin, pekerjaan, tingkat pendidikan, dan status gizi

\begin{tabular}{|c|c|c|c|}
\hline Gambaran Umum Subjek & & $\mathrm{n}$ & $\%$ \\
\hline \multicolumn{4}{|l|}{ Jenis kelamin } \\
\hline Laki-laki & & 20 & 57,1 \\
\hline \multirow[t]{2}{*}{ Perempuan } & & 15 & 49,2 \\
\hline & Jumlah & 35 & 100 \\
\hline \multicolumn{4}{|l|}{$\underline{\text { Kelompok Umur }}$} \\
\hline $35-44$ th & & 8 & 22,9 \\
\hline $45-54$ th & & 15 & 42,9 \\
\hline \multirow[t]{2}{*}{$55-64$ th } & & 12 & 34,3 \\
\hline & Jumlah & 35 & 100 \\
\hline \multicolumn{4}{|l|}{ Pekerjaan } \\
\hline Ibu Rumah Tangga & & 5 & 14,3 \\
\hline Karyawan swasta & & 10 & 28,6 \\
\hline Pensiunan PNS & & 1 & 2,9 \\
\hline Petani & & 2 & 5,7 \\
\hline PNS & & 8 & 22,9 \\
\hline \multirow[t]{2}{*}{ Wiraswasta } & & 9 & 25,7 \\
\hline & Jumlah & 35 & 100 \\
\hline \multicolumn{4}{|l|}{ Pendidikan } \\
\hline Tidak tamat SD & & 2 & 5,7 \\
\hline SD & & 5 & 14,3 \\
\hline SMP & & 4 & 11,4 \\
\hline SMA & & 13 & 37,1 \\
\hline \multirow[t]{2}{*}{ Sarjana } & & 11 & 31,4 \\
\hline & Jumlah & 35 & 100 \\
\hline
\end{tabular}

Pada tabel 1 terlihat bahwa jumlah subjek laki-laki (57\%) lebih banyak dari subjek wanita (49\%). Subjek rata-rata berumur 45 tahun ke atas. Hal ini sesuai dengan penelitian yang dilakukan oleh Kirkman dkk bahwa DM tipe 2 sering terjadi pada middle aged, dengan puncak onset pada usia 60 tahun. Berdasarkan hasil Riskesdas 2013, proporsi penyebab kematian akibat DM pada kelompok 4554 tahun di daerah perkotaan menduduki rangking ke-2, sebesar 14,7\%.5 Mayoritas subjek memiliki berpendidikan minimal SMA atau sederajad. Hasil penelitian Riskesdas tahun 2013 menunjukkan bahwa prevalensi DM cenderung lebih tinggi pada masyarakat dengan tingkat pendidikan tinggi. ${ }^{5}$ Terdapat indikasi bahwa semakin tinggi tingkat pendidikan seseorang, maka akan mempengaruhi tingkat pendapatan dan kemapanan dalam hidupnya, yang selanjutnya diikuti dengan pola konsumsi yang berlebihan sehingga berpeluang terkena DM Tipe $2 .{ }^{15}$ Sebagian besar subjek bekerja. Subjek yang memiliki pekerjaan ternyata lebih mudah menerima informasi dan diajak bekerjasama dalam proses edukasi. Sekalipun tingkat pendidikannya lebih rendah dibanding subjek yang tidak bekerja. ${ }^{16}$ 
Tabel 2. Gambaran subjek menurut status gizi

\begin{tabular}{lllll}
\hline \multirow{2}{*}{ Variabel } & \multicolumn{2}{c}{ Sebelum } & \multicolumn{2}{c}{ Sesudah } \\
\cline { 2 - 5 } & $(\mathrm{n}=35)$ & \multicolumn{3}{c}{$(\mathrm{n}=35)$} \\
\cline { 2 - 5 } & $\mathrm{N}$ & $\%$ & $\mathrm{n}$ & $\%$ \\
\hline Status gizi & 2 & 5,7 & 2 & 5,7 \\
Gizi kurang & 8 & 22,9 & 10 & 28,6 \\
Normal & 10 & 28,6 & 11 & 31,4 \\
Gizi Lebih & 11 & 31,4 & 9 & 25,7 \\
Obesitas I & 4 & 11,4 & 3 & 8,6 \\
Obesitas II & & & & \\
\hline
\end{tabular}

Tabel di atas menggambarkan status gizi pasien sebelum dan sesudah intervensi. Sebelum intervensi status gizi pasien 31,4\% mengalami obesitas I sedangkan setelah intervensi 28,6\% berstatus gizi normal dan $31,4 \%$ memiliki status gizi lebih. Rata-rata subjek memiliki status gizi lebih maupun obesitas. Kegemukan dan obesitas merupakan salah satu faktor risiko penyebab terjadinya DM. Obesitas dapat terjadi karena ketidakseimbangan asupan dan pengeluaran energi. Penelitian yang dilakukan oleh Sunjaya, menemukan bahwa individu yang mengalami obesitas berisiko 2,7 kali lebih besar untuk terkena DM dibandingkan individu yang tidak mengalami masalah obesitas. ${ }^{17}$

\section{KADAR GULA DARAH SUBJEK}

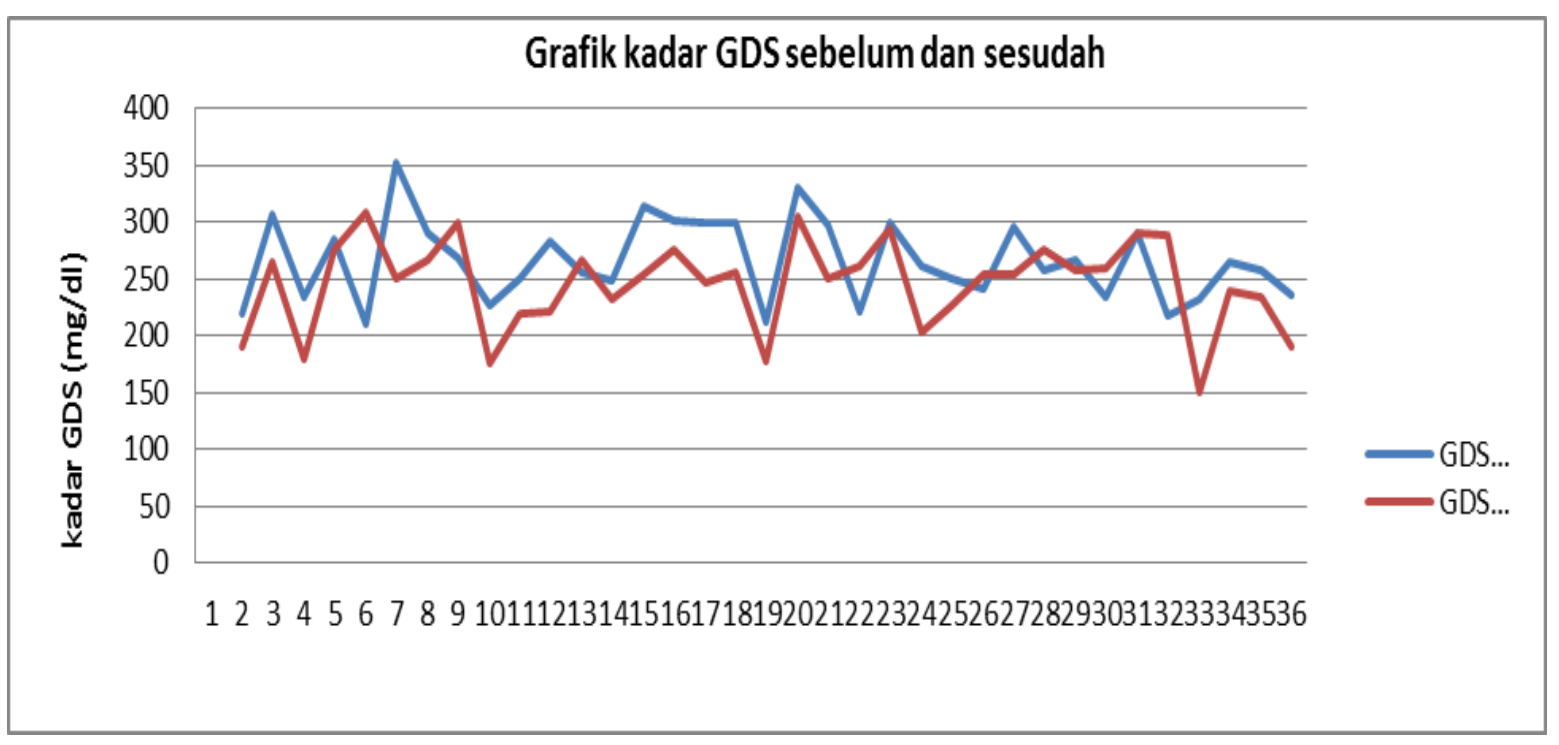


Grafik diatas menunjukkan kadar gula darah sewaktu (GDS) sebelum lebih tinggi dibandingkan dengan kadar GDS sesudah intervensi.
Gambaran kadar gula darah sewaktu subjek sebelum dan sesudah adanya pemberian konseling gizi dan ramuan jamu ditampilkan dalam tabel di bawah ini:

Tabel 3. Uji beda kadar gula darah sebelum dan sesudah pemberian konseling gizi

\begin{tabular}{|c|c|c|c|c|c|}
\hline \multirow[t]{2}{*}{ Jenis pengukuran } & \multicolumn{2}{|c|}{ Sebelum $\quad($ pre $) \mathrm{n}=35$} & \multicolumn{2}{|c|}{ Sesudah $\quad($ post $) \mathrm{n}=35$} & \multirow[t]{2}{*}{$\mathrm{P}$} \\
\hline & Rerata & SD & Rerata & SD & \\
\hline Nilai kadar gula $(\mathrm{mg} / \mathrm{dl})$ & 265,8 & 35,8 & 245,5 & 39,9 & $0,006^{*}$ \\
\hline
\end{tabular}

Keterangan :

*Uji t berpasangan

*Nilai normal kadar GDS $\leq 200$ mg/dl

Berdasarkan hasil uji statistik tberpasangan (tabel 3), terdapat perbedaan antara kadar gula darah sewaktu sebelum dengan sesudah pemberian konseling $(p<0,05)$. Sebagian besar subjek mengalami penurunan kadar gula darah (80\%). Konseling gizi mampu mengubah pengetahuan subjek yang pada akhirnya turut berkontribusi terhadap penurunan kadar gula darah subjek. Rerata kadar gula darah sewaktu setelah pemberian koseling masih di atas nilai $200 \mathrm{mg} / \mathrm{dL}$. Penurunan kadar gula dipengaruhi oleh banyak faktor, diantaranya adalah tingkat kepatuhan subjek/pasien dalam menjalani dietnya. ${ }^{16}$ Berdasarkan hasil wawancara dengan subjek, kadar gulanya masih tinggi karena subjek belum patuh terhadap anjuran dietnya. Frekuensi dalam mengkonsumsi sumber karbohidrat masih berlebihan. Subjek mengaku jika mengkonsumsi karbohidrat tidak hanya sebagai makanan utama namun juga sebagai selingan. Selain faktor kepatuhan diet, faktor lain yang mempengaruhi penurunan kadar gula adalah status gizi subjek. Di akhir penelitian diketahui masih banyak subjek yang memiliki status gizi lebih dan obesitas. Faktor lain yang mempengaruhi penurunan kadar gula darah antara lain tingkat stess dan tingkat aktivitas fisik yang dalam hal ini tidak diteliti.

\section{KESIMPULAN}

Intervensi gizi dan ramuan jamu untuk diabetes pada penderita DM tipe 2 di RRJ Hortus Medicus Tawangmangu mampu menurunkan kadar gula darah sewaktu.

\section{DAFTAR PUSTAKA}

1. Suyono S. Kecenderungan peningkatan jumlah penyandang diabetes dan Patofisiologi diabetes melitus. Dalam: Sugondo S, Soewondo P, Subekti I, editor (penyunting). Penatalaksanaan diabetes melitus terpadu. Edisi ke-2. Jakarta: FKUI; 2009. hlm. 7-18.

2. WHO. Diabetes (diunduh Maret 2014). Tersedia dari: URL: HYPERLINK

http://www.who.int/medicentre/factsheets/fs312/en/.

3. Gustaviani, R. Diagnosis dan Klasifikasi Diabetes Mellitus, Buku Ajar Ilmu Penyakit Dalam, Balai Penerbit Fakultas Kedokteran Universitas Indonesia1879, Jakarta. 2006 
4. Tjokroprawiro, Askandar. Hidup Sehat dan Bahagia Bersama Diabetes Melitus. Jakarta: Penerbit PT Gramedia Pustaka Utama. 2006.

5. Badan Litbangkes, Depertemen Kesehatan RI. Riset Kesehatan Dasar 2013: Laporan Nasional 2013. Diunduh bulan September dari: www.litbang.depkes.go.id

6. Sundaru. (2005). Diabetes mellitus: Apa dan Bagaimana Pengobatannya. FKUI.Jakarta. 2005

7. PERKENI. Konsensus Pengelolaan dan Pencegahan Diabetes Melitus tipe 2 di Indonesia 2011 (diunduh Maret 2014). Tersedia dari: URL: HYPERLINK

http://www.perkeni.org/download/Ko nsensus\%20DM\%202011.zip.

8. Miller CK, Edwards L, Kissling G, Sanville L. Nutrition Education Improves Metabolic Outcomes Among Older Adults With Diabetes Mellitus: Result From a Randomized Control Trial Preventive Medicine 2002.

9. Yessy Mardianti Sulistria. Tingkat Self Care Pasien Diabetes Melitus Tipe 2 Di Puskesmas Kalirungkut Surabaya. 2013

10. Arikunto, S. Analisis Data Penelitian Deskriptif. Dalam : Arikunto, S., ed. Manajemen Penelitian. Jakarta: PT. RINEKA CIPTA. 2007
11. Laporan Riskesdas 2010. Badan Litbang Kesehatan. Kementerian Kesehatan RI.

12. Peraturan Menteri Kesehatan No. 003/MENKES/PER/I/2010 tentang Saintifikasi Jamu dalam Penelitian Berbasis Pelayanan Kesehatan. Kementerian Kesehatan RI, 2010.

13. Eka Siswanto, dkk. 2011. Aktivitas Antidiabetes Kombinasi Ekstrak Terpurifikasi Herba Sambiloto Andrographis paniculata (Burn). F NESS dan Metformin pada Tikus DM Tipe 2 Resistensi Insulin. Majalah Obat Tradisional 16(3), 124-131, 2011.

14. Vademekum Tanaman Obat untuk Saintifikasi Jamu Jilid 1. 2012, Jakarta: Kementerian Kesehatan RI.

15. Fatmati, Ari. Faktor Risiko Kejadian DM Tipe 2 Pasien Rawat Jalan (Studi Kasus di RSUD Sunan Kalijaga Demak). FKM Universitas Negeri Semarang. 2010

16. Yoshepin P.Tjahyono, Calyptra. Pengaruh Edukasi Melalui Media Visual Buku Ilustrasi terhadap Pengetahuan dan Kepatuhan Pasien DM tipe 2. Jurnal Ilmiah Mahasiswa Universitas Surabaya vol.2 no.1. 2013

17. Betteng, Richardo. Analisi faktor risiko penyebab tjdinya DM tipe $2 \mathrm{pd}$ wanita usia produktif di Puskesmas Wawosa. Jurnal e-Biomedik(eBM) vol. 2 no. 2 Juli 2014 hal 404-412 